\title{
ABO Blood Groups and Ischaemic Heart Disease in Men
}

\author{
T. M. ALLAN AND AUDREY A. DAWSON \\ From the North-East Scotland Blood Transfusion Centre, Royal Infirmary, Aberdeen, and the Department of \\ Medicine, University of Aberdeen
}

In 1954 Gertler and White found a significant deficit of group $O$ patients in a series of 81 young male survivors of myocardial infarction. Between 1961 and 1966, a further 9 series of survivors of myocardial infarction were reported, and in 7 of these there was again a deficit of $O$ 's, the deficit being slight in 3 of the series but significant in 4 (Table I). Furthermore, Jaegermann (1962) found, in a series of 828 fatal cases, a significant excess of A's predisposed to ischaemic heart disease in general, as evidenced by early or well-marked atheromatous changes in the coronary arteries.

In view of these findings a survey has been made of 353 male survivors of ischaemic heart disease, with special reference to duodenal ulcer, age, occupation, and family history of ischaemic heart disease.

\section{Patients Selected}

The 353 patients were all from Aberdeen, a city whose relatively stable and homogeneous population makes it particularly suitable for such an investigation. To eliminate, so far as possible, patients not belonging hereditarily to north-east Scotland, only those were included who were Protestant and who had either a Scottish surname or an Anglo-Saxon surname common in Scotland (Registrar General for Scotland, 1962).

The 353 patients were divided into two groups-one of 202 in whom the first indication of ischaemic heart disease was myocardial infarction, and one of 151 in whom the first indication was either angina pectoris or acute coronary insufficiency. Patients in whom angina or acute coronary insufficiency was followed by infarction in less than one month were regarded as presenting with infarction. Of the 151 patients presenting without infarction, $103 \mathrm{had}$ one or more infarctions later.

The diagnosis of infarction was accepted only if there was unequivocal electrocardiographic evidence of recent infarction, or if appropriate rises in serum transaminase

Received August 30, 1967. levels occurred where myocardial changes were masked, as, for example, by a bundle-branch-block pattern. All cardiograms were assessed by the same observer (A.A.D.).

If the history fitted closely that given in the W.H.O. (1959) definition of angina pectoris, angina was considered to be present even in the absence of electrocardiographic changes. Post-exercise electrocardiograms were not taken routinely.

The category most difficult to define was that of acute coronary insufficiency. Patients placed in this category had all been admitted to hospital with ischaemic cardiac pain, of a type more severe and more prolonged than that of angina pectoris; and most of them had minor, transient electrocardiographic changes without any rise in serum transaminase levels. In many such patients other causes of similar pain-for example, hiatus hernia - had been ruled out.

\section{Data Obtained}

All the patients were blood-grouped before beginning long-term anticoagulant therapy. The grouping was done either before their discharge from hospital, or, as in some patients with angina, at the beginning of outpatient stabilization on this therapy.

In each case the following points were noted.

(1) The certain or probable existence of a present or past chronic duodenal ulcer, as evidenced by a strongly suggestive history, a positive barium meal, or an operation.

(2) The age at the last birthday before the onset of the first symptom of ischaemic heart disease.

(3) The occupation at the time of the first symptom. (At a later stage in the disease an artificial preponderance of light jobs would very probably have been found.) The type of work was classified as light, active, or heavy, according to the criteria of Morris and Crawford (1958).

(4) A history of probable ischaemic heart disease in first-degree relatives.

\section{RESULTS}

Blood Group Distribution. Despite theoretical objections (Allan, 1954, 1955; Buckwalter and 
TABLE I

INCIDENCE OF BLOOD GROUP O IN 10 EARLIER SERIES OF MYOCARDIAL INFARCTION PATIENTS

\begin{tabular}{|c|c|c|c|c|c|}
\hline \multirow{2}{*}{ Author(s) } & \multicolumn{2}{|c|}{ Number of $O$ patients } & \multicolumn{3}{|c|}{ Percentage of O's } \\
\hline & Observed & Expected & Patients & Controls & $\frac{\text { Difference }}{\text { S.E. }}$ \\
\hline $\begin{array}{l}\text { Jaegermann (1962) } \\
\text { Gjørup (1963) }\end{array}$ & $\begin{array}{r}25 \\
345\end{array}$ & $\begin{array}{r}23 \cdot 8 \\
343 \cdot 3\end{array}$ & $\begin{array}{l}34 \cdot 7 \\
40 \cdot 8\end{array}$ & $\begin{array}{l}33.0 \\
40.6\end{array}$ & $\begin{array}{l}0 \cdot 2 \\
0 \cdot 1\end{array}$ \\
\hline $\begin{array}{l}\text { Oliver and Cumming (1962) } \\
\text { Kalliomäki and Saarimaa (1962) } \\
\text { Pell and D'Alonzo (1961) } \\
\text { Gertler and White (1954) } \\
\text { Srivastava et al. (1966) } \\
\text { Neuman et al. (1961) } \\
\text { Bronte-Stewart et al. (1962) } \\
\text { Denborough, personal communication } \\
\quad(1965)\end{array}$ & $\begin{array}{r}101 \\
118 \\
101 \\
26 \\
17 \\
90 \\
215 \\
118\end{array}$ & $\begin{array}{r}102.2 \\
121.0 \\
109.8 \\
38.5 \\
27.3 \\
118.8 \\
267.6 \\
155.8\end{array}$ & $\begin{array}{l}49.5 \\
32.9 \\
44.7 \\
32.2 \\
19.5 \\
31.7 \\
34.0 \\
36.0\end{array}$ & $\begin{array}{l}50.1 \\
33.7 \\
48.6 \\
47.5 \\
31.4 \\
42.6 \\
42.3 \\
47.5\end{array}$ & $\begin{array}{l}0 \cdot 2 \\
0 \cdot 3 \\
0 \cdot 8 \\
2 \cdot 3 \\
2 \cdot 8 \\
3 \cdot 9 \\
4 \cdot 2 \\
4 \cdot 3\end{array}$ \\
\hline
\end{tabular}

TABLE II

ABO BLOOD GROUP DISTRIBUTION OF ABERDEEN MALE ISCHAEMIC HEART DISEASE PATIENTS

\begin{tabular}{|c|c|c|c|c|c|c|}
\hline \multirow{2}{*}{$\begin{array}{c}\text { Patients } \\
\text { presenting }\end{array}$} & \multirow{2}{*}{$\begin{array}{l}\text { Blood } \\
\text { group }\end{array}$} & \multirow{2}{*}{ Controls } & \multicolumn{4}{|c|}{ No. of ischaemic heart disease patients } \\
\hline & & & Observed & Expected & O-E & $\frac{(\mathrm{O}-\mathrm{E})^{2}}{\mathrm{E}}$ \\
\hline With infarction & $\begin{array}{l}\mathbf{O} \\
\mathbf{A} \\
\mathbf{B} \\
\mathbf{A B}\end{array}$ & $\begin{array}{r}3565 \\
2515 \\
771 \\
241\end{array}$ & $\begin{array}{r}82 \\
92 \\
24 \\
4\end{array}$ & $\begin{array}{r}101.6 \\
71 \cdot 6 \\
22.0 \\
6.9\end{array}$ & $\begin{array}{r}-19.6 \\
+20.4 \\
+2.0 \\
-2.9\end{array}$ & $\begin{array}{l}3 \cdot 8 \\
5 \cdot 8 \\
0 \cdot 2 \\
1 \cdot 2\end{array}$ \\
\hline Total & & 7092 & 202 & $202 \cdot 1$ & & $11 \cdot 0$ \\
\hline Without infarction & $\begin{array}{l}\text { O } \\
\text { A } \\
\text { B } \\
\text { AB }\end{array}$ & $\begin{array}{r}50.3 \% \\
35.5 \% \\
10.9 \% \\
3.4 \%\end{array}$ & $\begin{array}{r}71 \\
56 \\
20 \\
4\end{array}$ & $\begin{array}{r}75 \cdot 9 \\
53.5 \\
16.4 \\
5.1\end{array}$ & $\begin{array}{l}-4.9 \\
+2.5 \\
+3.6 \\
-1.1\end{array}$ & $\begin{array}{l}0.3 \\
0.1 \\
0.8 \\
0.2\end{array}$ \\
\hline Total & & $100 \cdot 1 \%$ & 151 & $150 \cdot 9$ & & $1 \cdot 4$ \\
\hline
\end{tabular}

Knowler, 1958), the subjects used as controls were a series of 7092 consecutively-registered blood donors from Aberdeen city. The ABO blood group distribution of these is almost exactly the same for men and women.

Table II shows that among our patients presenting with infarction the observed values differ significantly from expectation, due to a deficit of $O$ 's and an excess of A's $\left(\chi^{2}=11.0\right.$ for 3 d.f.; $\mathrm{p}<0.02$ ). Among our patients presenting without infarction, on the other hand, there is only a very slight deficit of O's and excess of A's. The $\mathrm{O} / \mathrm{A}$ difference between the two series is not significant, however.

Of the 71 O's presenting without infarction, 48 $(68 \%)$ had at least one infarction later. The corresponding incidence for the $56 \mathrm{~A}$ 's is only slightly higher-viz., 41 (73\%).

Duodenal Ulcer History. A history of duodenal ulcer was noted in $67(19 \%)$ of the 353 patients studied-a total that includes $42(27 \%)$ out of 153
O's, compared to only $15(10 \%)$ out of 148 A's. This O/A relative duodenal ulcer incidence (2.70) is higher than any other reported so far (Fraser Roberts, 1957, 1959). The excess of O's and deficit of A's (Table III) are significant both for total ulcer patients and for ulcer patients presenting without infarction.

Age and Occupation. In the series as a whole the mean age is 54.9 for the 153 O's and 52.4 for the 148 A's-a significant difference $(2.6 \times$ S.E. $)$. Table IV shows that there are more A's than O's in each age-group up to the age of 50, especially among patients presenting with infarction, and that there are fewer A's than O's in three of the four later age-groups, especially among patients presenting without infarction.

Table $\mathrm{V}$ shows that the mean age of the A's is significantly lower than that of the O's in respect of patients presenting with infarction who were engaged in light work $(2.5 \times$ S.E. $)$, and in respect of 
TABLE III

DISTRIBUTION OF ABERDEEN O AND A MALE ISCHAEMIC HEART DISEASE PATIENTS WITH AND WITHOUT A HISTORY OF DUODENAL ULCER

\begin{tabular}{|c|c|c|c|c|c|c|c|}
\hline \multirow{2}{*}{$\begin{array}{c}\text { Patients } \\
\text { presenting }\end{array}$} & \multirow{2}{*}{$\begin{array}{l}\text { Blood } \\
\text { group }\end{array}$} & \multicolumn{3}{|c|}{$\begin{array}{l}\text { Patients with history of } \\
\text { duodenal ulcer }\end{array}$} & \multicolumn{3}{|c|}{$\begin{array}{c}\text { Patients with no history of } \\
\text { ulcer }\end{array}$} \\
\hline & & Observed & Expected & O-E & Observed & Expected & O-E \\
\hline With infarction & $\stackrel{\mathbf{O}}{\mathbf{A}}$ & $\begin{array}{l}21 \\
13\end{array}$ & $\begin{array}{l}19 \cdot 1 \\
13 \cdot 5\end{array}$ & $\begin{array}{l}+1.9 \\
-0.5\end{array}$ & $\begin{array}{l}61 \\
79\end{array}$ & $\begin{array}{l}82 \cdot 5 \\
58 \cdot 2\end{array}$ & $\begin{array}{l}-21 \cdot 5 \\
+20.8\end{array}$ \\
\hline Without infarction & $\stackrel{\mathbf{O}}{\mathbf{A}}$ & $\begin{array}{r}21 \\
2\end{array}$ & $\begin{array}{r}13.6 \\
9.6\end{array}$ & $\begin{array}{l}+7 \cdot 4 \\
-7.6\end{array}$ & $\begin{array}{l}50 \\
54\end{array}$ & $\begin{array}{l}62 \cdot 4 \\
44 \cdot 0\end{array}$ & $\begin{array}{l}-12.4 \\
+10.0\end{array}$ \\
\hline Total & $\stackrel{0}{\mathbf{O}}$ & $\begin{array}{l}42 \\
15\end{array}$ & $\begin{array}{l}32 \cdot 7 \\
23 \cdot 1\end{array}$ & $\begin{array}{l}+9 \cdot 3 \\
-8 \cdot 1\end{array}$ & $\begin{array}{l}111 \\
133\end{array}$ & $\begin{array}{l}144 \cdot 9 \\
102 \cdot 2\end{array}$ & $\begin{array}{l}-33.9 \\
+30.8\end{array}$ \\
\hline
\end{tabular}

TABLE IV

AGE DISTRIBUTION OF ABERDEEN O AND A MALE ISCHAEMIC HEART DISEASE PATIENTS

\begin{tabular}{|c|c|c|c|c|c|c|c|c|}
\hline \multirow{3}{*}{ Age-group } & \multicolumn{6}{|c|}{ Patients presenting } & & \\
\hline & \multicolumn{3}{|c|}{ With infarction } & \multicolumn{3}{|c|}{ Without infarction } & \multicolumn{2}{|c|}{ Total } \\
\hline & $\mathbf{O}$ & $\mathbf{A}$ & A-O & $\mathbf{O}$ & $\mathbf{A}$ & A-O & $\mathbf{O}$ & $\mathbf{A}$ \\
\hline $\begin{array}{r}<40 \\
41-45 \\
46-50\end{array}$ & $\begin{array}{r}4 \\
4 \\
12\end{array}$ & $\begin{array}{r}6 \\
14 \\
18\end{array}$ & $\begin{array}{r}+2 \\
+10 \\
+6\end{array}$ & $\begin{array}{r}2 \\
8 \\
11\end{array}$ & $\begin{array}{r}3 \\
12 \\
12\end{array}$ & $\begin{array}{l}+1 \\
+4 \\
+1\end{array}$ & $\begin{array}{r}6 \\
12 \\
23\end{array}$ & $\begin{array}{r}9 \\
26 \\
30\end{array}$ \\
\hline $\begin{array}{l}51-55 \\
56-60 \\
61-65 \\
66+\end{array}$ & $\begin{array}{r}22 \\
22 \\
10 \\
8\end{array}$ & $\begin{array}{r}18 \\
19 \\
14 \\
3\end{array}$ & $\begin{array}{l}-4 \\
-3 \\
+4 \\
-5\end{array}$ & $\begin{array}{r}15 \\
19 \\
9 \\
7\end{array}$ & $\begin{array}{r}7 \\
11 \\
9 \\
2\end{array}$ & $\begin{array}{l}-8 \\
-8 \\
+0 \\
-5\end{array}$ & $\begin{array}{l}37 \\
41 \\
19 \\
15\end{array}$ & $\begin{array}{r}25 \\
30 \\
23 \\
5\end{array}$ \\
\hline $\begin{array}{c}<50 \\
51+\end{array}$ & $\begin{array}{l}20 \\
62\end{array}$ & $\begin{array}{l}38 \\
54\end{array}$ & $\begin{array}{r}+18 \\
-8\end{array}$ & $\begin{array}{l}21 \\
50\end{array}$ & $\begin{array}{l}27 \\
29\end{array}$ & $\begin{array}{r}+6 \\
-21\end{array}$ & $\begin{array}{r}41 \\
112\end{array}$ & $\begin{array}{l}65 \\
83\end{array}$ \\
\hline
\end{tabular}

TABLE V

DISTRIBUTION OF ABERDEEN O AND A MALE ISCHAEMIC HEART DISEASE PATIENTS, BY AGE AND OCCUPATION

\begin{tabular}{|c|c|c|c|c|c|c|c|}
\hline \multirow{2}{*}{$\begin{array}{c}\text { Patients } \\
\text { presenting }\end{array}$} & \multirow{2}{*}{$\begin{array}{c}\text { Type of } \\
\text { work }\end{array}$} & \multicolumn{2}{|c|}{$\begin{array}{c}\text { No. of } \\
\text { patients }\end{array}$} & \multicolumn{4}{|c|}{ Mean age of patients (yr.) } \\
\hline & & $\mathbf{O}$ & A & $\mathbf{O}$ & $\mathbf{A}$ & $\underset{(\mathrm{A}-\mathrm{O})}{\text { Diff. }}$ & $\frac{\text { Difference }}{\text { S.E. }}$ \\
\hline With infarction & $\begin{array}{l}\text { Light } \\
\text { Active } \\
\text { Heavy }\end{array}$ & $\begin{array}{l}44 \\
25 \\
13\end{array}$ & $\begin{array}{l}46 \\
27 \\
19\end{array}$ & $\begin{array}{l}55 \cdot 6 \\
55 \cdot 4 \\
53 \cdot 7\end{array}$ & $\begin{array}{l}51 \cdot 8 \\
52 \cdot 7 \\
53 \cdot 3\end{array}$ & $\begin{array}{l}-3.8 \\
-2.7 \\
-0.4\end{array}$ & $\begin{array}{l}2 \cdot 5 \\
1 \cdot 1 \\
0 \cdot 1\end{array}$ \\
\hline \multicolumn{2}{|c|}{ Total } & 82 & 92 & $55 \cdot 2$ & $52 \cdot 4$ & $-2 \cdot 8$ & $2 \cdot 3$ \\
\hline Without infarction & $\begin{array}{l}\text { Light } \\
\text { Active } \\
\text { Heavy }\end{array}$ & $\begin{array}{l}32 \\
27 \\
12\end{array}$ & $\begin{array}{l}18 \\
22 \\
16\end{array}$ & $\begin{array}{l}52 \cdot 9 \\
56 \cdot 2 \\
54 \cdot 7\end{array}$ & $\begin{array}{l}54 \cdot 8 \\
52 \cdot 5 \\
49 \cdot 6\end{array}$ & $\begin{array}{l}+1.9 \\
-3.7 \\
-5.1\end{array}$ & $\begin{array}{l}0 \cdot 8 \\
1 \cdot 4 \\
2 \cdot 1\end{array}$ \\
\hline \multicolumn{2}{|c|}{ Total } & 71 & 56 & $54 \cdot 5$ & $52 \cdot 4$ & $-2 \cdot 1$ & $1 \cdot 4$ \\
\hline
\end{tabular}

parients presenting without infarction who were engaged in heavy work $(2 \cdot 1 \times$ S.E. $)$.

Family History. Table VI gives the incidence of a history of probable ischaemic heart disease in first-degree relatives of O's and A's. It shows that the ratio of A's to O's is $0.94(17: 18)$ for those with a probably-affected father, and $0.60(15: 25)$ for those with one or more probably-affected brothers-a non-significant difference. It also shows that the ratio of A's to O's is $2.00(10: 5)$ for those with a probably-affected mother, and $0.36(5: 14)$ for those with one or more probably-affected sisters-a significant difference $\left(\chi^{2}=4.1 ; p<0.05\right)$.

\section{Discussion}

Blood Group Distribution. The deficit of O's in our myocardial infarction series accords with the general trend of the 10 earlier series listed in Table $\mathrm{I}$, and thereby strengthens the possibility that a deficit of O's will prove to be characteristic of series 
TABLE VI

INCIDENCE OF ABERDEEN O AND A MALE ISCHAEMIC HEART DISEASE PATIENTS HAVING ONE OR BOTH PARENTS AND/OR ONE OR MORE SIBS WITH A HISTORY OF PROBABLE ISCHAEMIC HEART DISEASE

\begin{tabular}{|c|c|c|c|c|c|c|c|}
\hline \multirow{2}{*}{$\begin{array}{l}\text { Probably- } \\
\text { affected } \\
\text { male } \\
\text { relatives }\end{array}$} & \multicolumn{3}{|c|}{ Number of patients } & \multirow{2}{*}{$\begin{array}{c}\text { Probably- } \\
\text { affected } \\
\text { female } \\
\text { relatives }\end{array}$} & \multicolumn{3}{|c|}{ Number of patients } \\
\hline & $\mathbf{O}$ & $\mathbf{A}$ & $\mathrm{A} / \mathrm{O}$ & & $\mathbf{O}$ & $\mathbf{A}$ & $\mathbf{A} / \mathbf{O}$ \\
\hline $\begin{array}{l}\text { Father } \\
\text { Brother }\end{array}$ & $\begin{array}{l}18 \\
25\end{array}$ & $\begin{array}{l}17 \\
15\end{array}$ & $\begin{array}{l}0.94 \\
0.60\end{array}$ & $\begin{array}{l}\text { Mother } \\
\text { Sister }\end{array}$ & $\begin{array}{r}5 \\
14\end{array}$ & $\begin{array}{r}10 \\
5\end{array}$ & $\begin{array}{l}2.00 \\
0.36\end{array}$ \\
\hline
\end{tabular}

of myocardial infarction patients. Similarly, the excess of A's in our infarction series accords with the finding of an excess of A's in 9 of the 10 earlier series-an excess which is slight or moderate in 6 of these series but significant in 3. At this stage, however, there is nothing on this point to be added to Bronte-Stewart, Botha, and Krut's (1962) discussion of the subject.

In their series of patients with angina pectoris alone, Bronte-Stewart et al. (1962) and Oliver and Cumming (1962) both found a slight excess of O's (Table VII) and a deficit of A's. As our own series of patients presenting without infarction (Table II) comprises patients presenting with either angina pectoris or acute coronary insufficiency, it is only partially comparable with these two earlier series. It appears, however, to point in the same direction, as it contains only a slight deficit of $O$ 's and excess of A's. (Bronte-Stewart et al. (1962) have discussed this subject also.) In a series of patients with myocardial ischaemia, for which the clinical criteria were not stated, Srivastava, Thakur, and Das (1966) found a significant deficit of O's (Table VII) and excess of A's.

Duodenal Ulcer History. As ischaemic heart disease has a strong association with duodenal ulcer, and as duodenal ulcer has a strong association with blood group $\mathrm{O}$; one would expect to find an excess of O's among ischaemic heart disease patients, instead of the deficit found so far (Table I). Moreover, in our own series a deficit of O's exists despite the presence of proportionately twice as many patients with a history of duodenal ulcer as there are in the general adult male population of northeast Scotland-viz., 19 per cent compared to 10 per cent (R. D. Weir, 1966, personal communication)-and despite the fact that our ulcer sub-series itself contains a significant excess of O's (Table III). For these reasons, the over-all deficit of O's, both in our own series and in three other series also consisting of patients undergoing anticoagulant therapy, i.e. those of Kalliomäki and Saarimaa (1962), BronteStewart et al. (1962), and Denborough (1962, and personal communication, 1965)-is unlikely to be the result of patients with duodenal ulcer having been excluded from anticoagulant therapy for fear of gastro-intestinal haemorrhage. Thus our results appear to suggest that if there should prove to be a real deficit of O's, or a real excess of A's, or both, in ischaemic heart disease, such a deficit or excess, or both, might prove to be confined to patients without a history of ulcer. In that event the question would arise as to whether the same situation exists, to a lesser extent, in relation to other diseases associated, or possibly associated, with $A$, and as to whether conflicting results in this connexion might be due, in part, to regional or national variations in ulcer incidence.

Age and Occupation. In Srivastava et al.'s (1966) Indian series the excess of A's over O's is much greater in the over-50's than in the under-50's; and in Bronte-Stewart et al.'s (1962) racially-mixed South African series the excess of A's is present in all but the over-70 age-group. In our own series, on the other hand, the excess of A's over O's is largely confined to the under-50's (Table IV); and

TABLE VII

INCIDENCE OF BLOOD GROUP O IN TWO SERIES OF ANGINA PECTORIS PATIENTS AND ONE OF MYOCARDIAL ISCHAEMIA PATIENTS

\begin{tabular}{l|c|c|c}
\hline \multicolumn{1}{c|}{ Authors } & $\begin{array}{c}\text { Evidence of ischaemic heart } \\
\text { disease }\end{array}$ & \multicolumn{2}{|c}{ Group O patients } \\
\cline { 3 - 4 } & Angina pectoris & Observed & Expected \\
\hline $\begin{array}{l}\text { Oliver and Cumming (1962) } \\
\text { Bronte-Stewart et al. (1962) }\end{array}$ & Myocardial ischaemia & 23 & $48 \cdot 0$ \\
\hline Srivastava et al. (1966) & $68 \cdot 0$ \\
\hline
\end{tabular}


the same trend occurs in Kalliomäki and Saarimaa's (1962) Finnish series, in which the mean ages are, respectively, 58.3 for the O's and 56.9 for the A's. These differences between the various series, if confirmed, might be due either to racial factors or to such interrelated environmental factors as climate, diet, and occupation. Thus, Morris and Crawford (1958) and Shapiro et al. (1965) found infarction to be relatively commonest in those engaged in light work, and angina in those engaged in heavy work; and it is precisely in the categories infarction with light work and non-infarction with heavy work that the mean age of the excess group in our own series-i.e., the A's-is found to be lowest, not only absolutely but also in relation to that of the deficient group-i.e., the O's (Table V). The possibility of environmental selection against the $\mathrm{ABO}$ blood group genes was first suggested by Hirszfeld and Hirszfeld (1919) in relation to climate, and by Hirszfeld (1928) in relation to social class. For details see Allan (1963).

Family History. There are known to be genetic as well as environmental factors in the causation of ischaemic heart disease (Gertler and White, 1954; Rose, 1964; Suri, Singh, and Tandon, 1966; Slack and Evans, 1966). Accordingly, interest attaches to our finding that the ratio of A's to O's among patients with a father who was probably affected with ischaemic heart disease is considerably, though not significantly, higher than the corresponding ratio for brothers, and to our similar finding that the ratio of A's to O's among patients with a probably-affected mother is significantly higher than the corresponding ratio for sisters (Table VI). As in the matter of occupation and age, however, far more data will be required to confirm or contradict these findings, and in this connexion account must be taken of the strength of Wiener's (1960) and Nevanllina's (1960) argument that the study of the blood groups in relation to disease is called in question, to an unknown extent, by the putative non-publication of negative findings. Perhaps the best counter to this objection would be the central organization of simultaneous surveys in several different areas, such as those conducted by Aird, Bentall, and Fraser Roberts (1953) and Aird et al. (1954). See also Allan (1954, 1955).

\section{SUMMARY}

In a series of 353 men with ischaemic heart disease, the incidence of the ABO blood groups is noted, with particular reference to duodenal ulcer, age, occupation, and family history of ischaemic heart disease.
There are three main findings. First, there is a significant deficit of patients of blood group $\mathrm{O}$ aged up to 50, despite a very high incidence of duodenal ulcer. Second, patients of blood group A engaged in light work and presenting with infarction, or engaged in heavy work and presenting without infarction, are significantly younger than other patients. Third, there is a significant difference between $A$ and $O$ patients in respect of the incidence of ischaemic heart disease in female first-degree relatives.

Two conclusions are reached. The first is that the deficit of $O$ 's in the series strengthens the evidence for the existence of a real deficit of $O$ 's with ischaemic heart disease. The second is that much more data will be needed to confirm or contradict the findings in relation to age, occupation, and family history.

We are grateful to Dr. R. L. Richards, Dr. T. B. Begg, and the late Dr. B. Bronte-Stewart for invaluable discussion of our project; to Professor H. W. Fullerton, Dr. H. B. M. Lewis, and Dr. G. E. B. Grove for helpful comment on our paper; to Mr. W. Z. Billewicz for Polish translation; and to Mr. William Brass for his statistical analysis of the data.

\section{REFERENCES}

Aird, I., Bentall, H. H., Mehigan, J. A., and Fraser Roberts, J. A. (1954). The blood groups in relation to peptic ulceration and carcinoma of colon, rectum, breast, and bronchus. Brit. med.f., 2, 315.

$\longrightarrow$, - and Fraser Roberts, J. A. (1953). A relationship between cancer of stomach and the ABO blood groups. Brit. med. F., 1, 799.

Allan, T. M. (1954). Blood groups and disease. Brit. med. f., 2,644 .

- (1955). Blood groups and disease. Brit. med. F., 2, 1206.

- (1963). Hirszfeld and the ABO blood groups. Brit. F. prev. soc. Med., 17, 166.

Bronte-Stewart, B., Botha, M. C., and Krut, L. H. (1962). ABO blood groups in relation to ischaemic heart disease. Brit. med. F., 1, 1646

Buckwalter, J. A., and Knowler, L. A. (1958). Blood donor controls for blood group disease researches. Amer. $\mathcal{F}$. hum. Genet., 10, 164.

Denborough, A. M. (1962). Blood groups and ischaemic heart disease. Brit. med. F., 2, 927.

Fraser Roberts, J. A. (1957). Blood groups and susceptibility to disease. Brit. F. prev. soc. Med., 11, 107.

- (1959). Some associations between blood groups and disease. Brit. med. Bull., 15, 129.

Gertler, M. M., and White, P. D. (1954). Coronary Heart Disease in Young Adults. Harvard University Press, Cambridge, Massachusetts.

Gjørup, L. (1963). Blood groups and coronary occlusion. Acta genet. (Basel), 13, 178.

Hirszfeld, L. (1928). Konstitutionsserologie und Blutgruppenforschung. Springer, Berlin.

, and Hirszfeld, H. (1919). Serological differences between the blood of different races. Lancet, 2, 675. 
Jaegermann, K. (1962). Miazdzyca tetric wiencowych a cechy grupowe krwi. Kardiol. pol., 5, 215.

Kalliomäki, J. L., and Saarimaa, H. A. (1962). The ABO$\mathrm{Rh}$ groups and myocardial infarction. Cardiologia (Basel), 41, 109.

Morris, J. N., and Crawford, M. D. (1958). Coronary heart disease and physical activity of work. Brit. med. $\mathcal{F}$., $2,1485$.

Neuman, J., Novizki, I., Bauerberg, J., and Steinberg, J. (1961). Distribucion de frecuencias de los grupos sanguineos del sistema ABO en los enfermos con infarto de miocardio. Rev. Asoc. méd. argent., 75, 534.

Nevanllina, H. R. (1960). Blood groups and disease. Lancet, 1, 1135.

Oliver, M. F., and Cumming, R. A. (1962). Blood groups and heart disease. Brit. med. F., $2,51$.

Pell, S., and D'Alonzo, C. A. (1961). A three-year study of myocardial infarction in a large employed population. F. Amer. med. Ass., 175, 463.

Registrar General for Scotland (1962). Annual Report. H.M.S.O., Edinburgh.
Rose, G. (1964). Familial patterns in ischaemic heart disease. Brit. F. prev. soc. Med., 18, 75.

Shapiro, S., Weinblatt, E., Frank, C. W., and Sager, R. V. (1965). The H.I.P. study of incidence and prognosis of coronary heart disease. F. chron. Dis., 18, 527.

Slack, J., and Evans, K. A. (1966). The increased risk of death from ischaemic heart disease in first degree relatives of 121 men and 96 women with ischaemic heart disease. F. med. Genet., 3, 239.

Srivastava, D. K., Thakur, C. P., and Das, M. (1966). ABO blood groups in relation to ischaemic heart disease. Indian Heart $\mathcal{F}$., 18, 140.

Suri, V. P., Singh, D., and Tandon, O. P. (1966). Familial patterns in coronary artery disease. Indian f. med. Sci., $20,321$.

Wiener, A. S. (1960). Modern blood group mythology. F. forens. Med., 7, 166.

World Health Organisation (1959). Hypertension and coronary heart disease: classification and criteria for epidemiological studies. Wld Hlth Org. techn. Rep. Ser. 168. 